\title{
PELATIHAN PEMBUATAN BRIKET BERBASIS LIMBAH PERTANIAN BAGI PEMUDA KARANG TARUNA KARYA MUDA, DESA PONTANG, KECAMATAN AMBULU KABUPATEN JEMBER
}

\section{TRAINING OF BRICKET MAKING BASED ON AGRICULTURAL WASTE FOR KARANG TARUNA KARYA YOUNG, PONTANG VILLAGE, KECAMATAN AMBULU, JEMBER DISTRICT}

\author{
Bambang Piluharto*1, Asnawati ${ }^{1}$, Ahmad Roziq ${ }^{2}$ \\ ${ }^{1}$ Jurusan Kimia, Fakultas Matematika dan llmu Pengetahuan Alam, Universitas Jember \\ Jl. Kalimantan No.37 Jember 68121 \\ ${ }^{2}$ Jurusan Akuntansi, Fakultas Ekonomi dan Bisnis, Universitas Jember \\ Jl. Kalimantan Jember 68121 \\ bampito.fmipa@unej.ac.id
}

\begin{abstract}
Karang Taruna Karya Muda adalah wadah dan pengembangan pemuda dari desa Pontang, kecamatan Ambulu Kabupaten Jember yang bergerak khususnya dalam bidang kesejahteraan sosial. Program kegiatan dari karang taruna selama ini lebih banyak membantu program dari pemerintahan desa seperti gotong royong, keolahragaan dan kegiatan peringatan hari besar nasional dan keagamaan. Kegiatan yang diarahkan pada tumbuhnya kewirausahaan bagi para pemuda belum banyak dilakukan. Wilayah desa Pontang sebagai daerah pertanian dan memiliki jumlah pemuda usia produktif yang banyak memiliki potensi untuk mengembangkan suatu usaha berbasis sumber daya lokal. Kegiatan pengabadian yang dilakuan oleh tim ini bertujuan mengembangkan keterampilan pemuda karang taruna melalui pembuatan briket dengan bahan baku utama limbah pertanian yang melimpah di desa Pontang. Bentuk kegiatan ini berupa penyuluhan dan pelatihan pembuatan briket. Kegiatan penyuluhan dilakukan dengan metode ceramah tentang potensi pemuda untuk berwirausaha, potensi limbah pertanian menjadi material yang bernilai ekonomis dan briket sebagai alternatif bahan bakar pengganti minyak bumi. Sementara pelatihan ditekankan pada pembuatan briket menggunakan limbah pertanian sebagai bahan bakunya. Setelah kegiatan pelatihan selesai kemudian dilakukan kegiatan pendampingan sampai perserta pelatihan yait u pemuda karang taruna mahir membuat briket. Hasil kegiatan yang diperoleh adalah pemuda karang taruna mendapatkan pengetahuan tentang potensi-potensi limbah pertanian menjadi barang yang bernilai ekonomi dan briket merupakan salah satu potensi tersebut. Selain itu pemuda juga mendapatkan ketrampilan pembuatan briket menggunakan bahan-bahan berbasis limbah pertanian.Luaran pelatihan ini berupa produk briket yang dibuat secara mandiri oleh pemuda karang taruna. Hasil pelatihan ini diharapkan dapat meningkatkan keterampilan wirausaha pemuda karang taruna khususnya dalam pembuatan briket dan mendorong para pemuda karang taruna untuk berwirausaha.
\end{abstract}

Kata kunci: briket, karang taruna, limbah pertanian, pelatihan, wirausaha

Abstract

Karang Taruna Karya Muda is a forum for youth development from the village of Pontang, Ambulu sub-district, Jember Regency which is engaged especially in the field of social welfare. The activity programs of the youth organization so far have mostly helped programs from village government such as mutual cooperation, sports and activities to commemorate national and religious holidays. There have not been many activities aimed at growing entrepreneurship for youth. The village area of Pontang as an agricultural area and has a large number of productive age youths has the potential to develop a local resource-based business. The service activities carried out by this team aim to develop the skills of youth youth organizations through making briquettes with the main raw material for agricultural waste which is abundant in the village of Pontang. The form of this activity is in the form of counseling and training in making briquettes. Extension activities are carried out by lecturing on the potential of youth to become entrepreneurs, the potential for agricultural waste to become economically valuable materials and briquettes as an alternative fuel to replace petroleum. Meanwhile the training emphasized on making briquettes using agricultural waste as raw material. After the training activities are completed, mentoring activities are carried out until the training participants are adept at making briquettes. The results of the activity obtained are youth youth groups who get knowledge about the potentials of agricultural waste into goods of economic value and briquettes are one of these potentials. In addition, youths also gain skills in making briquettes using agricultural waste-based materials. The output of this training is in the form of briquette products made independently by youth youth organizations. The results of this training are expected to improve the entrepreneurial skills of youth youth organizations, especially in making briquettes and encourage youth youth organizations to become entrepreneurs.

Keywords: briquette, youth organization, agricultural waste, training, entrepreneurship 


\section{PENDAHULUAN}

Salah satu kelompok masyarakat yang potensi menjadi motor penggerak kegiatan di desa adalah kelompok pemuda Karang Taruna. Desa Pontang memiliki karang Taruna dengan nama Karang Taruna Karya Muda. Karang taruna ini merupakan wadah pemuda dengan usia berkisar 18 sampai 30 tahun yang bergerak di bidang sosial yang mendukung terlaksananya program kegiatan desa. Namun demikian, selama ini kegiatan lebih banyak pada kegiatan-kegiatan sosial yang bersifat incidental seperti kerja bakti, sosialisasi program pemerintah, kegiatan peringatan hari Kemerdekaan RI contohnya seperti pada gambar 1 .

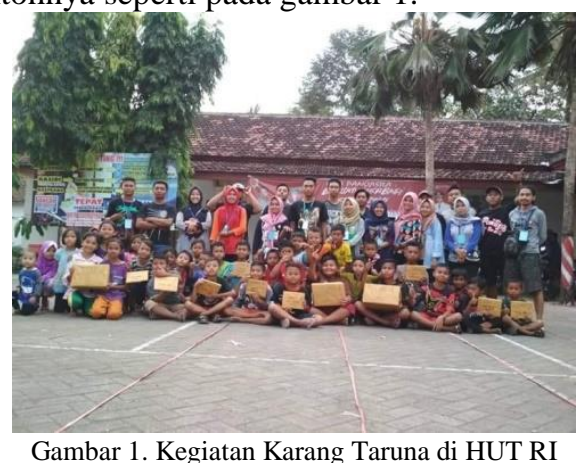

Kegiatan yang mengarah pada pemberdayaan pemuda melalui pembekalan maupun peningkatan keterampilan belum banyak dilakukan. Mengingat potensi yang dimiliki desa Pontang yang memiliki luas wilayah 1113,69 ha, dengan $42 \%$ wilayahnya adalah area persawahan yang digunakan sebagai lahan pertanian bagi penduduknya [1]. Potensi desa yang ada baik itu potensi sumber daya alam dari hasil-hasil pertanian maupun sumber daya manusia khususnya pemuda, maka perlu dilakukan suatu kegiatan yang diarahkan pada pemberdayaan ekonomi dalam jangka panjang dan peningkatan ketrampilan pemuda dalam jangka pendek.

Briket menjadi salah satu bahan bakar alternatif yang dinilai efektif untuk menggantikan minyak dan gas bumi yang semakin langka. Hal itu dikarenakan briket dapat dibuat dari bahan baku yang murah dan teknologi pembuatannya sederhana. Briket bisa dibuat menggunakan bahan baku dari limbah-limbah pertanian seperti tempurung kelapa, serbuk gergaji, jerami, sampah daun-daun kering [2,3]. Bahan-bahan berbasis limbah pertanian tersebut mudah diperoleh di desa Pontang yang mayoritas penduduk bergelut di bidang pertanian. Hal ini menjadi potensi untuk diolah menjadi bahan yang bernilai tambah secara ekonomis. Briket adalah salah satu pilihannya.

Berdasarkan hal tersebut, dapat dirumuskan permasalahan-permasalahan yaitu (1) mitra (Karang Taruna Karya muda) belum banyak memiliki pengetahuan tentang pemanfaatan limbah pertanian menjadi produk yang bernilai ekonomis. (2) mitra belum memiliki keterampilan dan pengalaman dalam pembuatan briket berbasis limbah pertanian

\section{TARGET DAN LUARAN}

Target yang diharapkan dari kegiatan ini adalah:

1. Mitra mendapatkan pengetahuan dan ketrampilan tentang pembuatan briket berbasis limbah pertanian

2. Mitra dapat memproduksi briket secara mandiri. Luaran yang diharapkan dari kegiatan ini adalah produk briket yang dihasilkan oleh mitra kegiatan.

\section{METODE PELAKSANAAN}

Untuk mencapai target solusi-solusi yang diusulkan, kegiatan ini dibagi dalam 3 tahap yaitu penyuluhan dan pelatihan (workshop) disertai pendampingan. Detail tahapan kegiatan ini diuraikan sebagai berikut,

1. Penyuluhan

Dalam penyuluhan ini akan dikenalkan mengenai briket dan bahan apa saja yang dapat digunakan untuk membuat briket arang. Selain itu, juga diberikan pengetahuan tentang potensi briket untuk kedepannya serta nilai potensi usaha yang cukup menjanjikan. Target dari penyuluhan ini dibuat untuk menggugah rasa semangat pemuda karang taruna dalam meningkatkan keterampilan dalam membuat briket. Akhir dari kegiatan penyuluhan ini pemuda Karang Taruna diberikan kuesioner untuk melihat tingkat antusias dan pemahaman terhadap kegiatan ini.

\section{Pelatihan Pembuatan Briket Berbasis Limbah} Pertanian

Pelatihan ini merupakan kelanjutan dari materi penyuluhan sebelumnya yaitu pengenalan briket arang dan bahan apa saja yang dapat digunakan membuat briket. Dalam tahap ini difokuskan pada praktek pembuatan briket dari limbah pertanian. Pelatihan dibimbing oleh tim pengusul dibantu oleh 2 orang mahasiswa. Pembuatan briket dari limbah pertanian pupuk organik dengan metode Takakura dibagi menjadi 4 tahap yaitu:

a. Penyiapan Bahan

Penyiapan bahan dilakukan dengan mengumpulkan limbah-limbah pertanian yaitu limbah jarak pagar, sekam padi, dan tempurung kelapa. Kemudian limbah yang berukuran besar dipotong kecil-kecil.

b. Pembuatan Briket

Pembuatan briket hasil optimasi yang dilakukan oleh Musabbikhah et al, 2015. Limbah jarak pagar, arang sekam padi, arang tempurung kelapa ditimbang dengan perbandingan 5:3:2:1 dari total berat briket $(600 \mathrm{~g})$ untuk cetakan sarang tawon (kotak) dan $100 \mathrm{~g}$ untuk cetakan silindris. 
Selanjutnya ditambahkan dengan perekat yang telah dicampur dengan air dan dipanaskan pada tungku elektrik. Bahan tersebut dicampur hingga homogen. Campuran bahan tersebut dimasukkan dalam cetakan mesin press. Pada saat pengepresan, tekanan diatur pada $225 \mathrm{~kg} / \mathrm{cm}^{2}$. Selanjutnya setelah terjadi pengepresan pada tekanan yang ditentukan, dilakukan penahanan selama waktu yang ditentukan yaitu 5 menit agar briket menjadi lebih padat. Setelah pencetakan selesai, briket dikeluarkan dari cetakan dan selanjutnya dilakukan pengeringan menggunakan oven pada suhu $60^{\circ} \mathrm{C}$ selama 3 hari $[2,4]$.

\section{IV.HASIL DAN PEMBAHASAN}

Pelaksanaan kegiatan ini dibagi menjadi 2 tahapan yaitu; (1) penyuluhan; dan (2) pelatihan pembuatan briket. Detail masing-masing tahapan diuraikan sebagai berikut,

1. Penyuluhan

Penyuluhan meliputi tentang potensi limbah pertanian menjadi material yang bernilai ekonomi seperti potensi menjadi pupuk organic, briket dan asap cair. Kegiatan ini diikuti 13 orang pemuda Karang Taruna, bertempat di balai desa Pontang, kecamatan Ambulu, kabupaten Jember. Materi penyuluhan terlampir. Peserta penyuluhan antusias menyimak kegiatan ini. Kegiatan ini ditutup dengan sesi tanya jawab (Gambar 2).

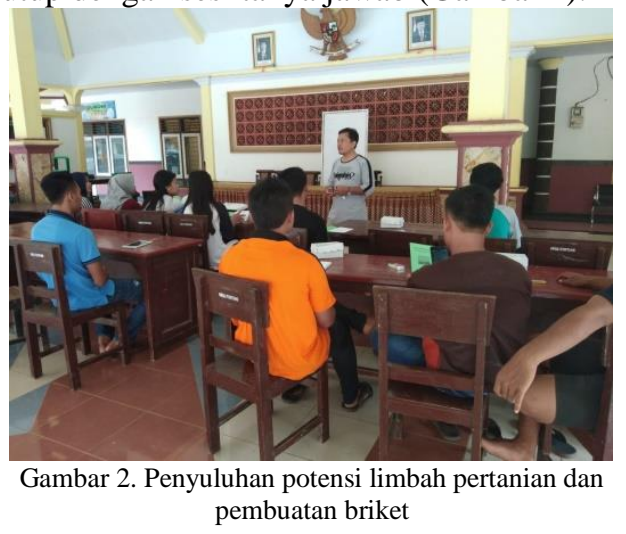

2. Pelatihan Pembuatan Briket

Pelatihan dilakukan setelah sesi penyuhan. Pelatihan pembuatan briket dimulai dari proses pengarangan, pembuatan serbuk arang, pembuatan adonan briket, pencetakan briket dan pemanasan.

\section{(a) Pengarangan}

Dua jenis sampel yang dijadikan contoh untuk pengarangan adalah sampel dari tempurung kelapa dan tongkol jagung. Pengarangan dilakukan dalam drum bekas, sampel tempurung kelapa atau tongkol jagung dibakar dengan oksigen terbatas selama kurang lebih 3 jam. Briket (b) Pembuatan Serbuk Arang

Hasil pengarangan kemudian dibuat serbuk sebelum dibuat adonan briket bersama dengan perekat. Pembuatan serbuk menggunakan mesin penggiling seperti ditunjukkan pada gambar 3 .

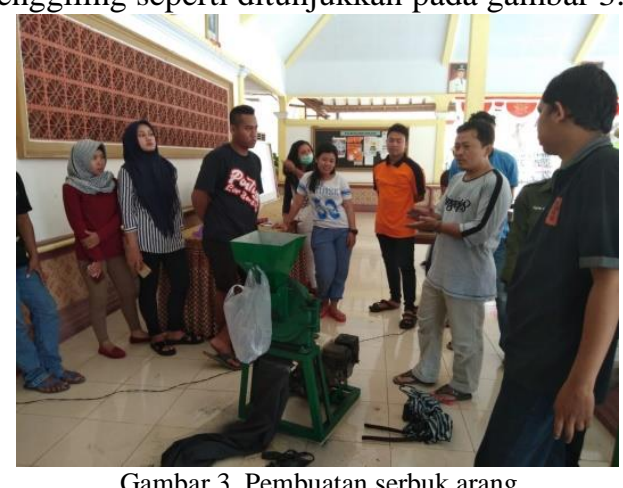

(c) Pembuatan Adonan Briket

Serbuk yang telah diperoleh selanjutnya dibuat adonan menggunakan perekat amilum (tepung kanji). Adonan ini terdidri dari 400 gram serbuk, ditambah 100 gram tepung kanji dan $100 \mathrm{~mL}$ air. adonan dibuat homogen melalui pengadukan (gambar 4).

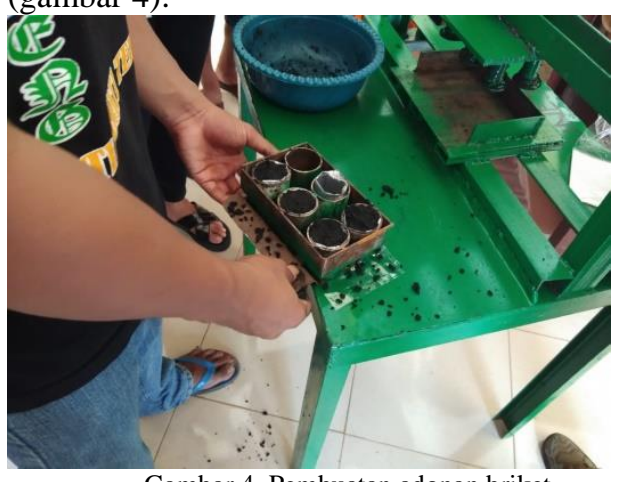

(d) Pencetakan Briket

Adonan dimasukkan dalam mesin pencetak briket. Dalam mesin pencetak ada 6 slot untuk adonan, sehingga setiap cetakan menghasilkan 6 briket basah. Hasil cetakan briket ditunjukkan pada gambar 5 dibawah ini.

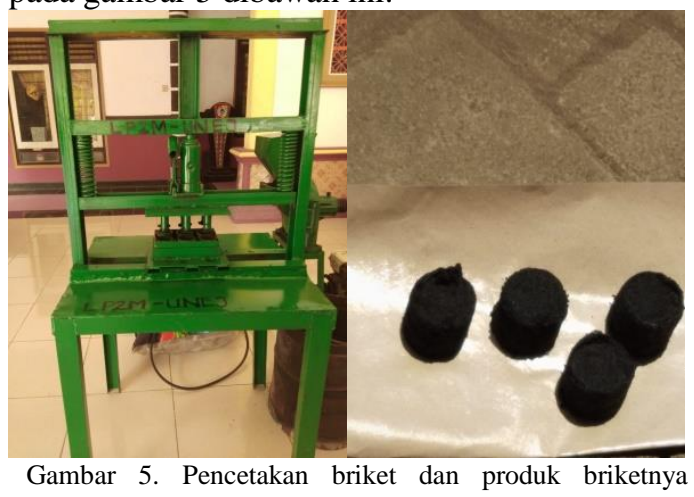




\section{(a) Pemanasan}

Pemanasan briket yang telah dicetak dilakukan selama 2 hari dibawah terik matahari. Sebenarnya bisa juga dilakukan juga dalam oven $60{ }^{\circ} \mathrm{C}$ selama 24 jam, namun dalam kegiatan ini pengeringan dilakukan dibawah terik matahari.

3. Uji Coba Briket

Setelah melewati proses pemanasan, briket diuji coba dalam tungku pemanas. Sampel yang diuji coba ini berasal dari bahan tempurung kelapa. Gambar 6 berikut adalah uji coba briket untuk pembakaran.

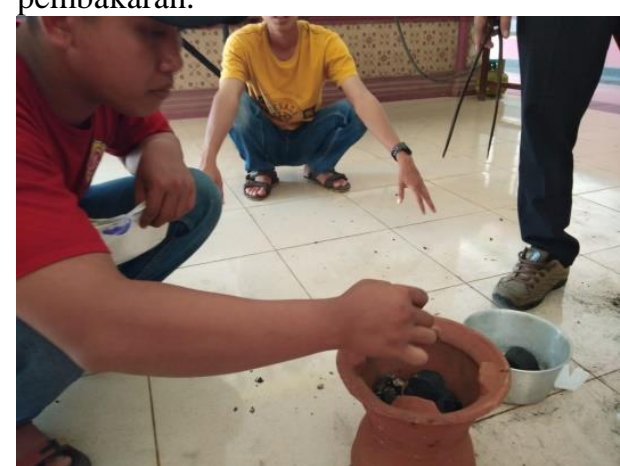

Gambar 6. Uji coba briket menggunakan tungku

\section{KESIMPULAN}

Berdasarkan hasil pengamatan selama pelaksanaan kegiatan pengabdian pada masyarakat ini maka kesimpulan yang dapat diambil adalah sebagai berikut :

1. Mitra kegiatan telah mendapatkan pelatihan berupa penyuluhan pemanfaatan limbah pertanian menjadi produk bernilai dan keterampilan pembuatan briket.

2. Mitra kegiatan berhasil secara mandiri membuat produk briket berbasis limbah pertanian.

\section{UCAPAN TERIMA KASIH}

Ucapan terimakasih disampaikan kepada LP2M Universitas Jember yang telah membiayai kegiatan pengabdian ini melalui Program Pengabdian Sumber Dana PNBP 2018.

\section{DAFTAR PUSTAKA}

[1] Katalog BPS, (2018), Kecamatan Ambulu dalam angka 2018 : Badan Pusat Statistik Kabupaten Jember, halaman 2

[2] Musabbikhah, M., Saptoadi, H., Subarmono, S., \& Wibisono, M. A. (2015). Optimasi Proses Pembuatan Briket Biomassa Menggunakan Metode Taguchi Guna Memenuhi Kebutuhan Bahan Bakar Alternatif Yang Ramah Lingkungan (Optimization of Biomass Briquettes Production Process Using Taguchi Method). Jurnal Manusia dan Lingkungan, 22(1), 121-128.

[3] Onukak, I. E., Mohammed-Dabo, I. A., Ameh, A. O., Okoduwa, S. I., \& Fasanya, O. O. (2017). Production and characterization of biomass briquettes from tannery solid waste. Recycling, 2(4), 17

[4] Septhiani, S., \& Septiani, E. (2015). Peningkatan Mutu Briket dari Sampah Organik dengan Penambahan Minyak Jelantah dan Plastik High Density Polyethylene (HDPE). Jurnal Kimia VALENSI, 1(2), 91-96. 